\title{
Jesus lei alle temas in die Bybel na die punt waar God hulle wil hê
}

\author{
Book Title: \\ Alle paaie lei na Jesus \\ Book Cover:

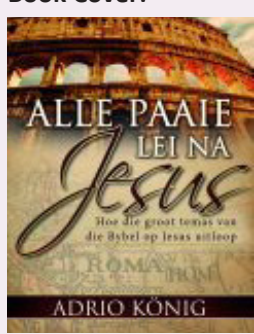 \\ Author: \\ A. König \\ ISBN: \\ 978-1-77000-781-9 \\ Publisher: \\ CUM, 2010, R119.95* \\ *Book price at time of review \\ Review Title: \\ Jesus lei alle temas in die \\ Bybel na die punt waar God \\ hulle wil hê

\section{Reviewer:} \\ Francois P. Viljoen

\section{Affiliation:} \\ ${ }^{1}$ Faculty of Theology, \\ North-West University, \\ Potchefstroom Campus, \\ South Africa \\ Email: \\ viljoen.francois@nwu.ac.za \\ Postal address: \\ 32 Van Graanstraat, \\ Potchefstroom 2531, \\ South Africa
}

How to cite this book review: Viljoen, F.P., 2012, 'Jesus lei alle temas in die Bybel na die punt waar God hulle wil hê', In die Skriflig/In Luce Verbi 46(1), Art. \#119, 1 page. http//dx.doi.org/ 10.4102/ ids.v46i1.119

(C) 2012. The Authors Licensee: AOSIS OpenJournals. This work is licensed under the Creative Commons Attribution License.
In die hierdie publikasie hanteer Adrio König 'n verskeidenheid temas in en oor die Bybel om om aan te toon hoe hierdie temas hulle vervulling in Jesus Christus vind. Hy sinspeel op die spreekwoord 'Alle paaie lei na Rome' en beredeneer dat as 'n mens die Bybel as geheel lees, jy sal sien hoe alle paaie na Jesus lei. In 11 hoofstukke bespreek hy die volgende temas:

- Abraham - geloof - verbond - besnydenis - doop: wanneer Jesus die nuwe verbond deur sy bloed instel, is dit 'n herbevestiging van die Abrahamverbond.

- Heil - saligheid: die gedagte van 'n geluksalige lewe na die dood by die Here in die hemel kom nie in die Ou Testament voor nie. Spore van hierdie idee is in die boek Daniël te vind, maar dié boek dateer uit 'n laat stadium van die totstandkoming van die Ou Testament. Groter duidelikheid oor die ewige saligheid word eers in die tyd van die Nuwe Testament gevind. Volgens die Nuwe Testament behels saligheid dat ' $n$ mens deur die geloof gemeenskap met Jesus en die Vader mag beleef, nou en tot in ewigheid.

- Die Wet: wat die Wet as lewensreël vir die volk van God betref, is daar volkome aansluiting en voortgang tussen die Ou en Nuwe Testament. Ten opsigte van die wet as heilsmiddel is daar egter 'n totale breuk vanweë die heil was Jesus vir gelowiges bewerk het.

- Skepping: om die betekenis van die skepping te verstaan, moet ' $n$ mens verder as Genesis 1 en 2 in die Bybel lees om ook die talle ander verwysings daarna te herken. Jesus was saam met die Vader volledig betrokke by die skepping. Deur sy versoening en vernuwing het Jesus die skepping sy doel laat bereik.

- Die mens: ' $n$ mens se betekenis en ewige bestemming word bepaal deur sy verhouding met Jesus Christus.

- Die verhouding tussen die Ou en Nuwe Testament: Jesus staan in die middelpunt van die hele Bybel. Die skrywers van sowel die Ou as die Nuwe Testament het na Hom en sy boodskap gesoek en dit gekry.

- Die vervulling van profesieë: talle Bybelse profesieë het hulle vervulling in Jesus gevind, hoewel dit soms op ' $n$ vrye en onvoorspelbare manier gebeur het. Ons kan grondige verrassings by die vervulling van uitstaande profesieë verwag.

- Israel, volke, kerk: die Ou Testament is in geheel die mislukte geskiedenis van Israel en die volke. Daarom is die Nuwe Testament en die totstandkoming van die kerk nodig.

- Die uittog uit Egipte: die verhaal van die uittog het besondere betekenis in sy oorspronklike konteks, maar daarbenewens ook toegepaste betekenisse. Nuwe-Testamentiese verwysings toon hoe die verhaal sy vervulling in die verlossing van Jesus vind.

- Die benamings van God: 'n verskeidenheid van Godsbenamings is in die Ou Testament te vind. Hierdie aanduidings is egter te vaag om daaruit af te lei dat die Ou-Testamentiese gelowiges die meervoudigheid van God in drie Persone geken het. Die Drie-Eenheid leer ons eers in die Nuwe Testament ken.

König sluit dan af met 'n slothoofstuk met die titel Alle paaie lei na Jesus waarin hy die voorafgaande temas tot ' $n$ konklusie saamtrek. Jesus lei alle temas in die Bybel na die punt waar God hulle wil hê.

Die werk getuig daarvan dat die skrywer rypheid het in die aanbieding van die spektrum van die temas wat hy beredeneer. ' $n$ Besondere winspunt van die publikasie is enersyds dat hy in teenstelling met baie teoloë wat die Bybel tot onsamehangende verhale en voorskrifte wil versnipper, aantoon dat daar dwarsdeur die Bybel 'n merkwaardige struktuur en gedagte-ontwikkeling bestaan. Die boek dien ook as teenvoeter vir die veldtog van sommige Bybelwetenskaplikes wat Jesus eensydig kleiner en minder belangrik probeer voorstel. Die skrywer skroom ook nie om die problematiek van moeilike vraagstukke, wat soms op 'n naïewe manier met oorvereenvoudigde dogmatiese uitsprake beantwoord word, aan die orde te stel nie. Die temas word op ' $n$ verstaanbare en verrykende manier aangebied. Die publikasie vertoon egter iets van die karakter van studienotas vir Bybelstudente oor die onderskeie temas, wat skynbaar by nabaat aan ' $n$ hooftema gekoppel word. Terwyl die outeur die gedagte dat alle paaie na Jesus lei as sentrale tema noem, kom hierdie tema nie op 'n samehangende en deurlopende manier by elke hoofstuk na vore nie. Die onderskeie temas word plek-plek en teen die einde ietwat kunsmatig aan Jesus gekoppel.

Die boek behoort aanklank te vind by ernstige Bybelstudente, tipies op 'n voorgraadse vlak. Die boek bring lesers op hoogte met die algemene debatte oor die bepaalde temas en dring hulle tot dieper nadenke. Die boek sou ook sinvolle gesprekke oor die temas kon stimuleer. 